Bogdan ŞTEFĂNESCU

Faculty of Foreign Languages and Literatures, University of Bucharest

Bucharest, Romania

bogdan.stefanescu@lls.unibuc.ro

\title{
EXILE IN REVERSE: CONSTANTIN NOICA AS AN EXAMPLE OF PARAEXILIC LIFE IN COMMUNIST ROMANIA
}

Recommended Citation: Ştefănescu, Bogdan. "Exile in Reverse: Constantin Noica as an Example of Paraexilic Life in Communist Romania." Metacritic Journal for Comparative Studies and Theory 5.2 (2019): https://doi.org/10.24193/mjcst.2019.8.01

Abstract: This article illustrates a relatively less charted form of exilic dislocation which I have dubbed paraexile. Unlike Claudio Guillén, who claims that exiled writers can triumph over their native attachments and create a literature of "counter-exile," I propose, alongside critics like Lamming, Rushdie, or Said, that the trauma of displacement can never be entirely left behind and is constantly part of exilic writing. In addition, I make the claim that paraexilic literature is a peculiar form of internalizing exile by means of irony and contradiction. I am illustrating this attitude with the work of Constantin Noica, one of the most popular and respected philosophers in post-war Romania, who rejected emigration and, instead, adopted the paradoxical solution of triumphing over internal and internalized exile by embracing it as a form of liberation. I am proposing the rhetorical category of contra-discourse-a dialogic structure of argument and narrative in which the homely and the foreign are spoken of in the ironically mingled voices of the oppressor and of the victim. I am concluding with the suggestion that, while the work of Noica is in many ways idiosyncratic, it may also be viewed as a typical form of coping with exilic traumas in Central and East European cultures during communism.

Keywords: Rhetoric of exile, paraexile, Noica, Central and Eastern Europe, communism, counter-discourse, resistance through culture, paradox. 
This article discusses a particular form of exile as exemplified in communist Romania by philosopher Constantin Noica, a man who, by all classical definitions of exile, was not an exile. He lived in Romania for all of his life and spent his last years in a place of his own choosing. On his retirement, he picked a remote and picturesque mountain resort, called Păltiniș, to live and write there for the remainder of his life. Not only did he refuse to emigrate and live in self-exile like his friends Emil Cioran and Mircea Eliade, but he also famously remarked - and this is engraved on a plaque outside the cabin where he spent his last years - that everyone else was an exile, not him: "Anyone who does not live in Păltiniș must feel exiled" (qtd. in Liiceanu 2010, 39) ${ }^{1}$. Why, then, talk about Noica as an exile? Because standard definitions of exile are ineffective when we are dealing with a particular aspect of exile as a subjective experience. In what follows here, I hope to provide a more accurate account of the intricacies of exilic experience in twentiethcentury Romania, one which may prove adequate for the critical investigation of living and writing under totalitarian duress in the rest of Eastern Europe as well. For that, I am reconceptualizing the notion of exile in such a way as to explain why the wilful withdrawal from a toxic political environment, even when exercised in your homeland, should still be thought of as an exilic condition, one whose intricacies defy binary logic. In the process, I will indicate some examples of this kind of exile with special attention given to Constantin Noica whose case is perhaps revealing for other home exiles in communist Eastern Europe.

\section{The Complexities and Complications of Exile}

Traditionally, the notion of exile is qualified by two oppositions: one between external and internal exile, the other between forced and wilful exile. These binary pairs are the result of a consideration of the material circumstances of exile. The criteria being used are: 1. who decides whether one should leave his home (hence forced vs. wilful exile) and 2. whether state boundaries are crossed or not, that is, whether exile takes place abroad or at home (which yields the external vs. internal exile opposition). If these criteria are applied simultaneously the following recognizable types of exile obtain:

1 “Oricine nu stă la Păltiniș trebuie să se simtă în exil.” My translation. 
EXILE IN REVERSE

FORCED

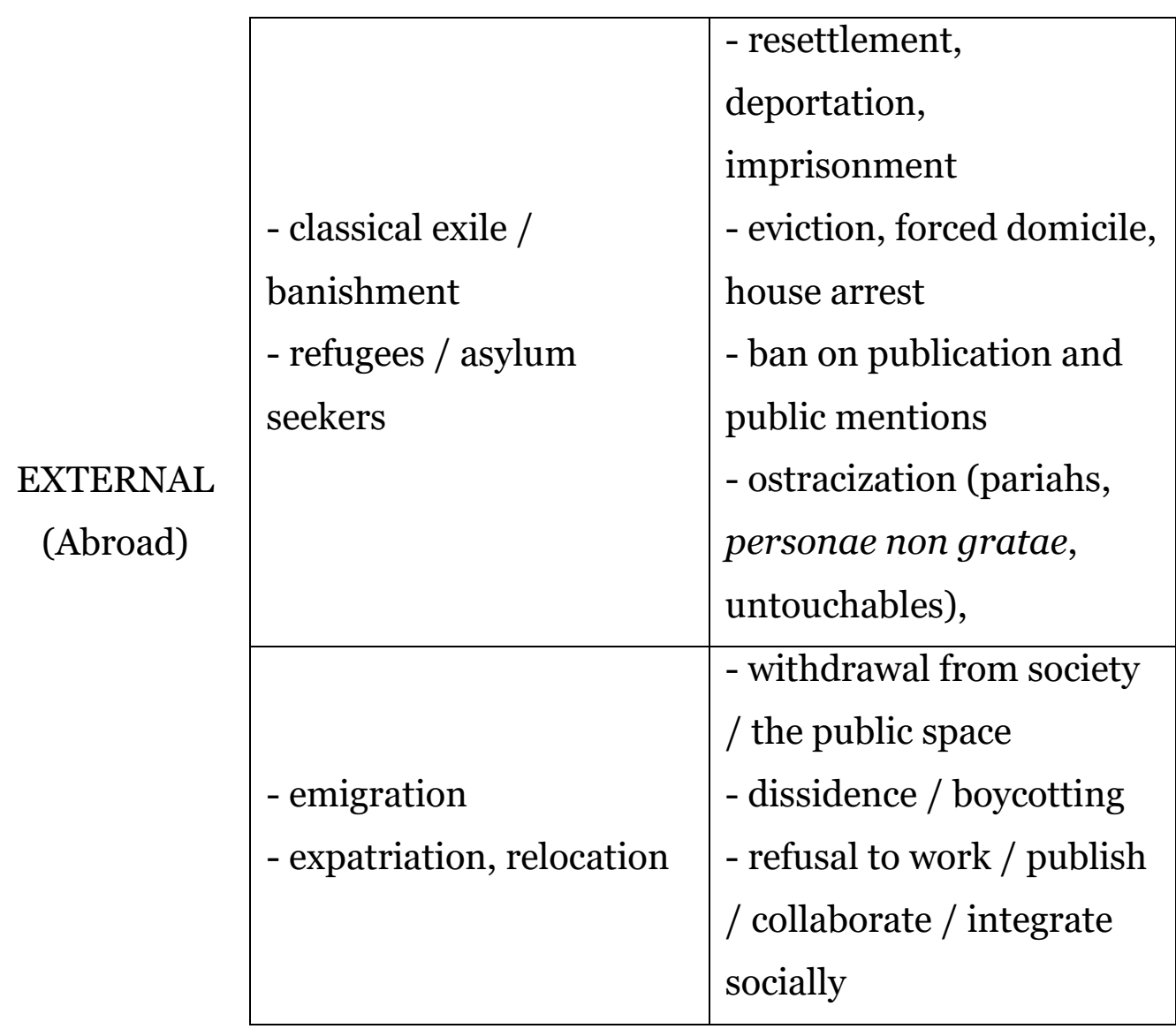

INTERNAL

(At home)

\section{WILLFUL}

Of the four resulting types, the forced external type of exile takes precedence in traditional understanding given the legal and political institution of exile in classical antiquity. Even more recent studies define exile as the experience of leaving one's homeland, although, when looking at examples from modern history, some scholars have had to admit that there is also a wilful type of exile abroad ${ }^{2}$. This can still be

\footnotetext{
2 "Exile is a condition in which the protagonist is no longer living, or able to live, in the land of his birth. It
} may be either voluntary, a deliberate decision to stay in a foreign country, or involuntary. In some cases, 
intuitively grasped: even if you choose to live abroad of your own accord, you may experience deracination that is in many ways similar to that of exiles on whom banishment was enforced by the authorities. But living in your home country and, even more so, doing it of your own accord - how can that be possibly conceived as exile?

Let us consider what a home really is. "Home" is not a static and unilateral notion; in other words, home is not home in or by itself. The meaning of having a home is relational and dynamic - it needs, even if only symbolically and mentally, movement to and from an elsewhere. Home is not just an address, a mere dwelling, a fixed geographic and civil location. And it is definitely not a space of confinement. It is the place you can leave from in order to explore otherness (other places, other cultures and societies, other modes and conditions of being, other perspectives on life). It is also where you can return for the alternative comfort of fixity and shelter. Home is a relative point of origin for your mental and identitarian map. Suspending the possibility of travel, of leaving home and of experiencing otherness and, so to say, elsewhereness all but cripples your very sense of belonging in a home, a place where your identity is anchored. The home stops being an origin if you deny its ability to originate interaction, movement, a change of location and of perspective. That is why one has to consider that living in reclusion or being evacuated from the general social sphere, whether coercive or self-inflicted, amounts in fact to an exilic condition.

But the analysis and the conceptual boundaries of exile have been expanded even more by considering not so much the palpable circumstances of exile (such as coercion and location), but rather the inner world and mental attitudes of exiles. Claudio Guillén, a Spanish-American literary figure and a forced external exile from Spain, famously complicated our view on the matter in his 1976 essay On the Literature of Exile and Counter Exile. According to him, "the literature of exile" (for which Ovid is a perfect example) is directly focused on exile which it takes as its principal subject matter. This kind of writing is a nostalgic testimonial of loss and displacement, a lyrical and autobiographical record of the trauma of exile. By contrast, "the literature of counter-

exile can be merely the result of circumstances, such as an offer of expatriate employment. Such instances will usually cause little hardship to the protagonist. However, exile may be enforced. This last occurrence frequently results from a major difference of political disagreement between the authorities of a state and the person being exiled" (Claassen 9). 
exile (such as that of Mickiewicz) exhibits a tendency toward integration, increasingly broad vistas or universalism," it is a form of "triumph over the separation and thus can offer wide dimensions of meaning that transcend the earlier attachment to place or native origin" (272). Guillén's categories have meant a welcome addition to our critical vocabulary because they pointed not so much to the external conditions of exile, as to the discursive attitudes and to the subjective dimension of exile. However, they also entrapped our understanding of exilic consciousness in the sparse mechanism of binaries, of an either/or and his literature of counter-exile seems a rather idealized and utopian escape from exilic trauma if one compares it with the accounts of theorists like Edward Said for whom the exilic strain remains an "unhealable rift forced between a human being and a native place, between the self and its true home: its essential sadness can never be surmounted." Unlike Guillén, Said felt that "while it is true that literature and history contain heroic, romantic, glorious, even triumphant episodes in an exile's life, these are no more than efforts meant to overcome the crippling sorrow of estrangement" (173). Yet other critics have felt that Guillén's simple oppositional scheme has serious limitations which become evident if one looks at examples such as that of the late Jewish-Hungarian writer Imre Kertész, who claimed that:

There exists a country where I was born, whose citizen I am, and especially whose beautiful language I speak and read, and write my books in; this country, however, has never been mine, has never belonged to me - rather I belonged to it, and for four decades it proved to be much more my prison than my homeland (qtd. and translated by Suleiman in Neubauer and Török 374).

Susan Rubin Suleiman has looked at the perplexing life of Kertész and found that, like all internal exiles of totalitarian regimes, he experienced a paradoxical condition: "He knows that his own relation to the system is that of an outsider, and he also knows (here is the paradox) that his status of an outsider is his by choice as much as by necessity. Or, if you will, it is by an internal necessity: he can do no other" (qtd. and translated by Suleiman in Neubauer and Török 374). Sophia McClennen has also thoroughly critiqued "a binary logic where exile either produces creative freedom or it traps the writer in restrictive nostalgia" (2) and has proposed a dialectical understanding whereby "exile 
identity is the unity of these opposite tendencies" (32-33). Such theoretical positions seem to be validated by such ambivalent exilic experiences as that of the willing-tocompromise Georg Lukács in Galin Tihanov's astute account:

The foundational paradox of Lukács's life after 1945 is that while he always enjoyed a measure of prestige and a fair share of the public spotlight, he nonetheless suffered inner isolation over prolonged periods of time. At the same time as he was protected and offered a way of life that on the face of it bespoke privilege and material comfort, he was also left with the bitter aftertaste of being used for party-political purposes, with his ability to resist or extricate himself from this process declining over time. Promoted and vilified in the same breadth, Lukács was a hostage to forces beyond his control, a loyal soldier of his Party (at times hovering at the margins or simply excluded from it) rather than a powerful policy-maker (Neubauer and Török 138).

I agree with McClennen and Suleiman that we need a more refined epistemology to deal with the complexities and contradictions of exile. But, rather than be sidetracked by the material circumstances of exile in a totalitarian or in a global environment, I intend to focus on precisely the subjective nature of exile as a traumatic experience. Exile is thus internalized (not to be confused with the territorially internal exile) by a process whereby the subject experiences what I would call a "paraexilic" condition. Paraexile amounts to a paradoxical representation of the liminal status wherein the exile finds him/herself indecisively and contradictorily poised between the binary categories of wilful/forced or external/internal exile. The complications of paraexile can be glimpsed by looking at such examples as Tihanov's depiction of Lukács' exile and return or Sandra Pouchet Paquet's glossing on George Lamming's The Pleasures of Exile. Pouchet Paquet draws our attention to "the paradox and ambiguity of spatial and psychic disjunction wrought by the whole etiology of the Caribbean as a colonial enterprise" and she declares that for Lamming "exile is a site of both alienation and reconnection" (134-5).

Cases like those of Lukács and Lamming, together with that of Noica which I will be detailing below, are proof that the paraexilic condition is an entirely subjective experience which can occur in all concrete circumstances of exile, be they external or internal, forced or wilful. Unlike Guillén's exile and counter-exile, which take territorial 
displacement for granted, the paraexilic condition is ultimately paraterritorial, by which I mean that it does not directly depend on physical borders and dislocations, although paraexiles may invoke such territories symbolically. This is why Lamming can declare that "the pleasure and the paradox of my own exile is that I belong wherever I am. My role, it seems, has rather to do with time and change than with the geography of circumstances" (50). And yet, in spite of his apparent detachment and cosmopolitanism, Lamming constantly identifies himself in terms of symbolic geography as a West Indian or Caribbean. In the process of absorbing coloniality, he internalizes at one the same time the expulsion presupposed by exile, as well as the "insideness" of belonging to his besieged homeland, opposites that are merged into the vexing mental experience of simultaneously living at home and abroad.

\section{Noica's Paraexile and His Contradiscursive Tactics}

Returning to Noica, I believe that he stands as a perfect example for the convoluted nature of the paraexilic condition. To fully grasp the paradox behind his claim that "anyone who does not live in Păltiniș must feel exiled" we must view it against the broader context of his life and writing. This will help us understand that, while he picked Păltiniş himself to be his new home on retirement, his choice was at once forced and free. It will also indicate why, although he never defected or got himself banished, Noica's decision to invoke exile in connection with Păltiniş is both accurate and significant, although it is phrased through an inversion.

A reputed translator and commentator of Greek philosophy, and the Hegelian creator of an ontology, a cultural morphology, and an innovative system of logic, Noica was more widely acclaimed for his philosophical nationalism that came mostly in the form of Heideggerian interpretations of apparently unassuming Romanian words and idioms (even prepositions) for which he found unexpected profound meanings. Noica suffered at the hands of the communist regime for his brief association with a fascist Romanian movement (the Iron Guard), for his "unhealthy" descent from a country squire, and for his possession and distribution of prohibited writings. He was stripped of his possessions and marginalized for most of his life. Starting from 1949 he lived for nine years under house arrest in a forced domicile in southern Romania (CîmpulungMuscel). He was then imprisoned between 1958-1964 for an exchange of letters with 
émigré writer Emil Cioran and for possession of forbidden books. During his house arrest and detention, Noica was banned from publishing. On his release from prison in 1964, he had to agree to cooperate with the communist regime. As a result, the ban on his publications was lifted and he was allowed to take up a job with the Romanian Academy's Centre for Logic (1965-1975)3. He continued to be summoned by the Securitate (the communist secret police) and had to be cautious about what he published, especially because of the idealist bent of his philosophy which ran contrary to the materialism of the official Marxist dogma.

On his retirement in 1975, Noica decided to rent a tiny room in a cabin in the Transylvanian mountain resort of Păltiniș. There he continued to study, write, and provide guidance to aspiring young intellectuals who sought him as a guru for their spiritual training. It was mostly during his retirement years at Păltiniș that Noica gained a nation-wide popularity even outside philosophical and literary circles, mostly due to the publication of Jurnalul de la Păltiniș (The Păltiniș Diary) in 1983, in which Gabriel Liiceanu, one of Noica's disciples, provided a passionately intellectualist narrative of the private seminars and personal interaction between Noica and the members of the socalled Păltiniș School/Group. The book turned the recluse philosopher and his devotees into stars. By the time of his death in 1987, he had become famous as a quirky philosophical hermit, a champion of sophisticated Romanian nationalism, and the object of countless intellectual pilgrimages.

For almost two decades, Noica copiously experienced the various hardships of forced internal exile: eviction, forced domicile and house arrest, ostracization, imprisonment, and a ban on his publications. Yet Noica converted his exile into a badge of honour as shown by the (self-)ironic way in which he responded to a famous letter addressed to him by his long-time friend Emil Cioran:

we are beginning to understand that your destinies are duller: even your exile is commonplace as it risks leading you to "nostalgia," patriotism and feeling. How little, really, compared to our subtle exile, an exile among your own people, sometimes even at home, in your own world, and yet entirely emptied of it. At times, when we are being

3 Cf. Ștefănescu, Constantin Noica for a more detailed account of Noica's life and work. 
sophisticated, we find it interesting and we write journals and masterpieces - for our secret drawers. Tout compte fait, we are better off here" (Răspuns al unui prieten îndepărtat [Response from a Faraway Friend] in Marino 309).4

So when was Noica telling the truth - when he claimed that the chosen place of his selfexile, Păltiniș, was his genuine home, while the rest of the world, especially Cioran's Paris - and Western Europe in general - really meant to live in exile or when he told Cioran that he felt exiled among his own people? These paradoxical reversals are meant to compensate both for the tortures and humiliation inflicted on Noica by the communist repression, and for his equally traumatic sense of marginalization by Western Europe. With his unmistakable rhetoric, Noica hones in on the paraexilic condition as a contradictory subjective experience. After being marginalized and merely tolerated during his fifteen years of forced domicile and incarceration, and bitterly aware that he will always be a peripheral Eastern European, Noica's self-inflicted exile was at once forced and free, not unlike that of Kertész.

His selected place of exile is also relevant. The small mountain resort of Păltiniş, far away from the political and cultural centre of Romania, played a symbolic role: Noica was at once accepting the marginal status granted him by the communist authorities but also countering from a periphery of privilege. Cioran, who was himself a master of hurt pride and paradoxical quipping, called out his friend's disingenuous stratagem of selfassertion: "in Romania, Noica played the role of a conqueror; that is why his solitude was never a renunciation, it was a triumph" (qtd. in Laignel-Lavastine 293).

Indeed, Păltiniş lies at the very centre on the map of Romania, in the mid-range of the Carpathians, and it is literally next door from the birthplaces of Emil Cioran himself and of other canonical figures of nationalist writing such as Octavian Goga or Lucian Blaga. Cornel Ungureanu remarks that Păltiniș meant withdrawal into a "sacred space," an inner sanctum of the national spirit, and alternative cultural capital for the spiritual rebirth of Romania (Ungureanu 10). Let me just add that Noica's retreat to

4 "Am început să înţelegem că e mai multă platitudine în destinele voastre: pînă şi exilul vostru e banal, care riscă să vă ducă la «nostalgie», patriotism şi sentiment, ce puţin lucru este el faţă de exilul nostru subtil, exil printre ai tăi, la tine acasă uneori, în lumea ta, şi totuşi dintr-o dată vidat de ea. Cîteodată, cînd rafinăm şi noi, lucrul ni se pare chiar interesant, şi atunci scriem jurnale sau opere geniale - pentru sertare. Tout compte fait, e mai bine aici." My translation. 
Păltiniş also reenacted a topos in much of Romanian historiography: that of the Romanians strategically withdrawing inland from all sorts of invaders to the wooded mountains at the centre of Romania. Such retreats included the anticommunist resistance groups which survived in the mountains not far from Păltiniş until as late as the 1960s. Mircea Eliade, another of Noica's close friends, extrapolated from this commonplace military strategy the more metaphysical notion of a "terror of history" (30-1) supposedly at the heart of the Romanian people. The mid-Carpathians where Păltiniș is located seem to be the traditional home for a recurrent matrix of indirect resistance which informs the old retreat from foreign invaders, as well as both the armed resistance and the so-called "resistace through culture" against the onslaught of communism5.

It appears, then, that when Noica went to Păltiniş on his partially self-inflicted and less glamorous exile, he did it out of a frustrated sense of superiority and sophistication. While apparently admitting defeat in an effort to twist his fate around, Noica clamoured that peripheral European intellectuals like himself are really the champions of the true spirit of Europe (l'esprit de finesse), which he thought was banished from a degraded Western civilization and left homeless in the world: "Perhaps the spirit of Europe is wandering, triumphant and disconsolate, across the globe, ready to leap into our good God's interplanetary void" (Cioran 148). In the last interview he gave, Noica claimed that the book that he was working on at the time and which was to be his last (The European Cultural Model) was "the protest of a marginal European against true Europe which has stopped recognizing itself as such" (Cârdu 14).

These unexpected reversals were part of Noica's paraexilic rhetoric, his response to the invasive and malignant presence of both the communist and the capitalist versions of modernity. Clearly, the marginal mountain abode of Noica's selfsequestration is really a surreptitious centre from which he hoped to undermine the complicated hierarchies and geographies of his cultural trauma. Noica's ambivalent rhetoric in the face of his being fatally dislocated by both the Western and Soviet versions of colonialism-by-modernization is both intriguing and seductive. Caught

5 For a more detailed account see Ștefănescu, The Regenerative Void 131, Filling in the Historical Blanks 114-8. For a discussion of "resistance through culture" see Letiția Guran's Aesthetics: A Modus Vivendi in Eastern Europe?. 
between the two bullying civilizational models and forced to see himself as a marginal or ersatz European, Noica pretends to have found a discreet "third way" that is not entirely liberated from the two, but rather ambiguously placed between rejecting and being rejected, a perfect example of paraexilic subjectivity:

There really is something else beyond the two worlds [i.e., the capitalist West and the communist bloc] that are opposed to each other today. They are now no longer of interest, for there is another more subtle thing, the third human condition facing the two existing ones. The child from a certain moment in life becomes a third person: what the parents want from him and what they have invested in him does not matter. It is of no consequence at all what the tree wants after it has shed its seed. From a certain moment onwards, it matters no longer what the states or governments want, in the face of the human person whom they have directly or indirectly favoured: this person has by now entered another kind of evolution under another kind of law (Pray for Brother Alexander 43).

In Pray for Brother Alexander, as in many of his other texts, at least two different narrative voices collide and coexist in ironic dialogism (to use M. Bakhtin's terms): both the philosophical polemicist and the detached wit, both the official wooden-tongue Marxist and the stylish idealist, both the crude, single-minded vociferator and the clever sophist. Though his tone vacillates between pride and humility, Noica never loses sight of his ultimate objective, the reversal of defeat into victory and, before anyone could enjoy it (including himself), of victory into defeat:

Anyone who has kept an open mind and, above all has remained uninvolved under a communist regime, will have realized that the results of such a regime are strange. The revolution is eventually in favour of the rich, not the poor, because the rich have been deprived of their wealth, which means little, whereas the poor are deprived of their idealised objective of becoming rich. A man deprived of his ideal - which, at this level gives a meaning to life - is, in a certain way, annihilated. On the other hand, he who once had possessions and through them became alienated, could find himself rehabilitated, or even reinvested as a human being (Pray for Brother Alexander 42-3). 
In such passages as this, Noica is dialectically speaking in tongues. He is at once impersonating Marx and Hegel whom he ironically pits against each other only to allude, this time self-ironically, to his own destiny. Noica preserves the vocabulary of Marx's prophetic revolutionarism and anti-capitalism with the sole reason of flipping it over and proving that the disinherited rich are the unintended real beneficiaries of the communist revolution, while the poor are its victims. As always with irony, this is a selfreflective form of victory by self-abasement. Noica is also obviously alluding to his own status as a former aristocrat from a wealthy family, now disowned and debased by the new communist order, and, yet, not entirely a loser for that. Stripped of his material possessions by the communists, Noica was free to enjoy a more authentic, impalpable wealth.

Like Lamming and Kertész, Noica illustrates how paraexilic consciousness embraces a contradictory language. In an unsettling way, this idiom joins together and plays against each other both the nostalgic discourse of exile and the solar discourse of counter-exile (in Guillen's vocabulary). This special language I have called contradiscourse (not to be confused with the counter-discourse of direct opposition), that is, a dialogical co-mingling of the dialects of official and dissenting ideologies, of nationalism and internationalism, of identity trauma and identity celebration (Ștefănescu, Remembrance 16-17). This dual discourse can be seen as the very locus of paraexilic experience. After all, the real site of any home is language - homes are built through/as language. And so are exiles. Abusive regimes are notorious, among other things, for destroying the idiomatic sense of dwelling by maiming or dislocating native discourses. Victims of colonial or totalitarian oppression are symbolically evicted from their home language, entrapped in a forced domicile of words which the rigid official ideology, a wooden idiom mineralized into veritable prison walls. One of the ways in which the imprisoned subject can fight this linguistic exile is to recover the flexibility of language and its dynamic relation with difference and otherness. But in the face of censorship, this has to be done from within the prison-house of the official idiom, which is both accepted and undermined - it has to be done as a paraexile. 


\section{Conclusion. Paraexile and Central/Eastern Europe}

This article was meant to further the critique of binarism in accounts of exile literature and to offer an alternative methodology to deal with the paradoxes and dialectic of exile as suggested by the already quoted Rubin Suleiman and McClennen ${ }^{6}$. Such an approach could work around both the traditionalist oppositions between enforced and chosen exile and the subjectivist dissociation of exile literature as either creatively liberated and cosmopolitan or as a captive of nostalgic regression. It may also offer an epistemic complement to sophisticated analyses such as that conducted by Tihanov of the relationship between a supposed central literature produced in the homeland and the peripheral work of exiles.

While I have concentrated here on the exemplary Romanian destiny and work of Constantin Noica, I propose that similar accounts may be given for other Central and East European exilic personalities, as this troubled cultural area was prominent in the history of modern exile. It is no accident that Said constructs his critical exilic stance on the theoretical scaffolding of Central European refugees like Adorno, Auerbach, or Curtius $(184-5,259)$ and that, when he discusses the trope of traveling theory, he takes his cue from Fanon's appropriation of Lukács (451). In Said's view, such figures are constitutive of modernist consciousness as well as of much of anti- and post-colonial critique?.

Even more so, paraexile should be considered an explanatory tool for all kinds of exiles from communist Europe. In what amounts to no less than an internal colonization, Soviet-imposed regimes in Eastern Europe displaced a significant minority of undesirables such as dissidents and opponants, nonaligned intellectuals, people of "unsound" family origins, or former members of the middle and upper classes. Soviet communism promised to deliver the many by ostracizing their exploiters and domestic

6 There are, of course, many other texts dedicated to the intricacies of exile as life and writing experience, not least of which is Edward Said's Reflections on Exile where he mentions the "contrapuntal juxtapositions" in the habits of life, expression and activity of exiles (186). Let me just point the reader to Paul Friedrich's account of the ambivalence of exile (Rădulescu 177-8) and Domnica Rădulescu's anatomy of the paradoxes of exile (195 and foll.).

7 Indeed, Central and Eastern Europe is spectrally present in Third World anticolonialist discourse, among other things, as the source for theoretical positions such as Marxism, Leninism, or psychoanalysis and also as a memento of the potential threats posed by Soviet domination and by the specter of Africa's Balkanization. 
enemies (when it did not simply exterminate them) in various ways. As a result, many Romanians, like their East European neighbours, were living in exile at home. The paraexilic intellectuals from this region - whether abroad or at home, whether rejects or recluses - generally phrased their self-image through paradoxical reversals and ironic dialogism. In such contradiscursive texts the voices of the languages of the oppressor and of the oppressed contaminate and mutually subvert each other in the effort of the paraexilic subject to cope with cultural dislocations under the severe scrutiny of censorship (Ștefănescu, The Joke 21-24). Susan Rubin Suleiman has keenly observed, for instance, this ambivalent status in the case of György Konrád whom she sees as:

an 'internal exile' writer who is at the same time highly respected as a politically dissident intellectual; paradoxically, the dissident is part of the system, which after all tolerates dissidence up to a point (...) and he is also part of the 'counter-system' just as Hamvas was in an earlier and more difficult time" (Neubauer and Török 371).

One finds across Central and Easter Europe related symptoms of the paraexilic condition such as indecision or ambivalence in the writer's cultural and territorial sense of belonging, the carnivalesque and self-parodic "orchestration of voices" à la Bakhtin. Examples of ironic and dialogical "contra-discourse" are variously to be found, to name just a few, in Imre Kertész's bitter meditation on the paradoxes of traumatic dislocation and of cultural domination (the essays "The Language of Exile" and "A számüzött nyelv" [The Exiled Language]), in Paul Goma's dialogical use of narrative voices (his novel Ostinato), in Milan Kundera's culturally and philosophically ambivalent skepticism, in the texts of Czech writers like Věra Linhartová, Daniela Hodrová, and Bohumil Hrabal or of the Serbian Milorad Pavić - a livresque, detached, and self-referential or intertextual type of literature - to say nothing of Czesław Miłosz, the "saint of paradox" who "was at home in exile" (cf. also Beauchamp, Snel 388-95, Zuzana Stolz-Hladká 153 and passim, Cristina Șandru 284-5).

And yet, clever and charming as it was, indeed even unavoidable in some accounts, this contradictory strategy has unfortunately failed to shelter East European writers not only from communist oppression, but also from their latter day anticommunist critics who have charged them with evasionism and with having 
ambiguously adopted both a subversive and a compliant discourse (Șandru 120-6). But such are, to paraphrase Lamming, the pleasures of paraexile.

\section{References:}

Beauchamp, Scott. “At Home in Exile.” Review of Mitosz: A Biography, by Andrzej Franaszek. Dublin Review of Books, 1 July 2017, http://www.drb.ie/essays/athome-in-exile, accessed 2 December 2019.

Cârdu, Petru. "Ultimul interviu al lui Constantin Noica." Dilema, vol. 1, no. 31, 1993: 1415 .

Claassen, Jo-Marie. Displaced Persons: the literature of exile: from Cicero to Boethius. Duckworth, 1999.

Chitnis, Rajendra A. Post-Communist Russia and Eastern Europe. The Russian, Czech and Slovak fiction of the Changes. 1988-1998. Routledge Curzon, 2005.

Eliade, Mircea. The Fate of Romanian Culture. Translated by Bogdan Ştefănescu, Athena, 1995.

Friedrich, Paul. "Binarism versus synthesis: Eastern European and Generic Exile." Realms of exile: nomadism, diasporas, and Eastern European voices, edited by Domnica Rădulescu, Lexington Books, 2002: 159-184.

Guillén, Claudio. "On the Literature of Exile and Counter Exile." Books Abroad, vol. 50, no. 2, Spring 1976: 271-80.

Guran, Letiția. “Aesthetics: A Modus Vivendi in Eastern Europe?” In Marx’s shadow: knowledge, power, and intellectuals in Eastern Europe and Russia, edited by Costica Bradatan and Serguei Alex Oushakine, Lexington Books, 2010: 53-72.

Laignel-Lavastine, Alexandra. Filozofie și naționalism. Paradoxul Noica (Philosophy and Nationalism. The Noica Paradox). Humanitas, 1998.

Lamming, George. The Pleasures of Exile. U of Michigan P, 1992.

Liiceanu, Gabriel. Întâlnire cu un necunoscut (Meeting with a stranger). Humanitas, 2010.

---. Jurnalul de la Păltiniş (The Păltiniș Diary). Humanitas, 1991.

Marino, Adrian, editor. Revenirea în Europa (The Return to Europe). Aius, 1996.

McClennen, Sophia. The Dialectics of Exile: Nation, Time, Language, and Space in Hispanic Literatures. Purdue UP, 2004. 
METACRITIC JOURNAL FOR COMPARATIVE STUDIES AND THEORY 5.2

Neubauer, John, and Borbála Zsuzsanna Török, editors. The Exile and Return of Writers from East-Central Europe. A Compendium. De Gruyter, 2009.

Noica, Constantin. Istoricitate şi modernitate (Historicity and Modernity). Capricorn, 1990.

---. Modelul cultural european (The European Cultural Model). Humanitas, 1993.

---. Pray for Brother Alexander. Translated by Wendy Muston. Noica Anthology, edited by C. George Sandulescu, Contemporary Literature Press, 2010: 38137 (Photocopy of the $1^{\text {st }}$ edition, [No place], J. B. Roberts, 1994), editura.mttlc.ro/carti/noica.doing-time.pdf\#zoom=75\%, accessed 2 December 2019.

Pouchet Paquet, Sandra. Caribbean Autobiography: Cultural Identity and SelfRepresentation. University of Wisconsin Press, 2002.

Rădulescu, Domnica. “Theorizing Exile.” Realms of Exile: Nomadism, Diasporas, and Eastern European Voices, edited by Domnica Rădulescu, Lexington Books, 2002: 185-204.

Said, Edward. Reflections on Exile and Other Essays. Harvard UP, 2000.

Şandru, Cristina. Worlds Apart? A Postcolonial Reading of post-1945 East-Central European Culture. Cambridge Scholars Publishing, 2012.

Snel, Guido. "Gardens of the mind, places for doubt: Fictionalized autobiography in East-Central Europe." History of the Literary Cultures of East-Central Europe: Junctures and Disjunctures in the 19th and 2oth Centuries, vol.1, edited by Marcel Corniș-Pope and John Neubauer, John Benjamins, 2004: 386-400.

Ştefănescu, Bogdan. "Constantin Noica." The Literary Encyclopedia, www.litencyc.com/php/speople.php?rec=true\&UID=13291, accessed 2 December 2019.

---. "Filling in the Historical Blanks: A Tropology of the Void in Postcommunist and Postcolonial Reconstructions of Identity." Postcolonial Europe? Essays on PostCommunist Literatures and Cultures, edited by Dobrota Pucherová and Róbert Gáfrik, Brill|Rodopi, 2015: 107-20.

---. "Remembrance of Things Post: Revisiting the Trauma of Communism in Style." University of Bucharest Review, vol. XV (III), no. 1, 2013: 7-19. 
---. "The Joke Is on You: Humor, Resistance through Culture, and Paradoxical Forms of Dissent in Communist Romania." The Tropics of Resistance: Languages, Genres, Rhetoric, special issue vol. I of Miscellanea Posttotalitariana Wratislaviensia, no. 1, 2016: 17-24.

---. "The Regenerative Void: Avatars of a Foundational Metaphor in Romanian Identity Construction." Philologica Jassyensia, vol. VII, no.1 (13), 2011: 127-139.

Stolz-Hladká, Zuzana. "Human Existence as Strangeness and Writing as Estrangement Aspects of Exile in the Texts of Vera Linhartová." Canadian-American Slavic studies. Revue canadienne-américaine d'études slaves, vol. 33, no. 4, 1999: 153177, DOI: 10.1163/221023999Xo0148.

Tihanov, Galin. "Narratives of Exile: Cosmopolitanism Beyond the Liberal Imagination." Literary Thought, no. 1-2, 2012: 7-24.

Ungureanu, Cornel. "Noica şi careul M al Sibiului (Noica and Sibiu's M Quadrangle)." România literară, no. $\quad 34, \quad 24-30 \quad$ August 2012: http://arhiva.romlit.ro/index.pl/noica_i_careul_m_al_sibiului, accessed 2 December 2019. 